\title{
Client Satisfaction of the Reformed Health Services at Rural Health Units/ Centers.
}

\author{
Dr. / Amal A. K. Hussein ${ }^{1}$ And Dr. /Nermin M. Eid ${ }^{2}$, \\ PhD. Community Health Nursing ,Faculty of Nursing \\ PhD. Nursing Administration ,Faculty of Nursing, Menoufiya University
}

\begin{abstract}
:
Background: Client satisfaction may be considered to be one of the desired outcomes of care, even an element in health status itself. It is futile to argue about the validity of patient satisfaction as a measure of quality.

Aim: This study amid to identify the effect of quality management system on client satisfaction of the health services at Rural Health Unit/ Center.

Design: Ex post facto research design was used in this study.

Setting: The study was conducted in two health care units and two health care centers affiliated to Ashmoon and Shebin Elkom which were randomly selected.

Sample: A simple random sample of 400 clients from the selected settings was included in this study.

Tools: Interviewing questionnaire sheet was used to measure client satisfaction about the health services at the Rural Health Units and Health Centers and observational checklist using the accreditation tool: It was developed by Ministry of Health \& Population and used by the researcher to measures the quality of the health services in the pre mentioned units and health centers.

Findings: The majority of the studied clients were females. Regarding satisfaction from privacy during consultation, all the studied clients in Ashmoon were satisfied compared to 54\% in Kafer Tanbedy unit. In addition, $34 \%$ and $16 \%$ of the studied sample reported no physical examination in Kafr Tanbedy health unit and Shanshour unit respectively. The majority of the clients in the unit and health centers were satisfied from the quality of services at the lab and the pharmacy. The majority of the studied sample suggested availability of a specialist and female gynecologist, also, availability of medication; sonar and operating room were suggested. Conclusion: quality management system has had positive implications regarding client satisfaction in most studied areas.

Recommendation: Recruit female Gynecologists and social specialist in the units and health centers. Allocate more resources for providing $X$ ray etc. More supervision and continues monitoring is required. Further research is recommended to include health care personal (nurses, physician and worker).
\end{abstract}

Keywords: Client satisfaction, health sector reform, quality management system

\section{Introduction}

Patient satisfaction has a long history in the assessment of consultations and patterns of communication and is amongst the best means of assessing the interpersonal aspect of care. It is defined as "an evaluation based on the fulfillment of expectations. Evaluation of patient satisfaction has become a standard part of evaluation of a health care system. Meeting patient expectations has become one of the main objectives of health care providers ( Bu-Alayyan, et.al. 2008) . Satisfaction is achieved when the patient/client's perception of the quality of care and services that they receive in healthcare setting has been positive, satisfying, and meets their expectations (Doherty, 2003).

The idea of health reform was raised as a vision of the National Party in 1986. It aimes to promote the Family Health Model (FHM) as the new system of family based primary health care. The FHM offers families a basic package of integrated services (called the basic benefit package) in PHC-facilities called Family Health Units/ Centers. The basic benefit package includes basic family planning, Maternal and Child Health, reproductive tract infections and sexually transmitted infections, physicians act as gatekeepers to the higher levels of care (Ministry of Health and Population and Central Department for Technical Support and Projects, 2004).

Primary Health Care (PHC) service is the most frequently used in any health care system. It is defined by the World Health Organization (WHO) as essential health care made universally accessible to individuals and families in any community by means acceptable to them. The objective of primary health care is to deliver integrated health care services for the population (Al-Doghaither et.al. 2000). Health centers generally offer preventive and curative services, mostly adapted to local needs. Dispensaries are meant to be the system's first line of contact with patients, but in some areas, health centers or even hospitals are effectively the first points of 
contact. Dispensaries provide wider coverage for preventive health measures, which is a primary goal of the health policy (Muiruri, et.al.2012).

Delivering quality service has significant relationship with customer satisfaction, customer retention, loyalty, costs profitability and service guarantees (Boshoff and Gray, 2004). However, the poor state of customer service in some public centers has resulted in high turnover and weak morale among staff. This make it difficult to guarantee 24-hour coverage resulting in, problems with patients care, increased cost of operations due to inefficiencies leading some patients to look for an alternative provider and to spread negative word of mouth which affects potential clients hence growth of the hospital (Tam, 2005).

The quality of health services has a number of important implications. It affects the outcomes that a health system can achieve directly, through patient treatment, and indirectly, by encouraging or discouraging use of the services. It also affects staff morale, because working in an environment where employees know that the treatment quality is poor is not motivating. Substantial evidence indicates that the quality of care is often suboptimal and varies widely within countries. In part this suboptimal quality is attributable to resource constraints, but providing good-quality care is possible even in resource-poor settings (The International Bank for Reconstruction and Development / TheWorld Bank, 2006).

Unfortunately, many policymakers assume that quality assurance requirements have been satisfied by inclusion of regulation and accreditation measures. In fact, quality assurance is, and always has been, much broader than the application of regulatory mechanisms (Pan American Health Organization, 2005).

Accreditation of health care organizations has been in practice in many countries over the world. There is evidence that health care organizations rapidly increase compliance with the published standards in the months prior to the external assessment and improve organizational

processes . However there is less evidence that this is beneficial in terms of clinical process and outcome (Shaw, 2003). A quality management system has been implemented in Egypt in the recent years. It was started in primary health care units and now has been extended to hospitals (Al Tehewy et. al.,2009). Accreditation program (AP) has the objective of supporting the quality of primary health care (PHC) services. Accreditation program is implemented in Family Health Units that represent a shift from fragmented vertical PHC services, into comprehensive, integrated and continuous services (Abdel-Razik et al., 2012).

\section{Significance of the study}

Evaluation of patient satisfaction has become a standard part of evaluation of a health care system, and meeting patient expectations has become one of the main objectives of health care providers. The importance of meeting the expectations of the population by health care providers is widely accepted as one of the indicators of a functioning system. It is becoming increasingly recognized that patient's views should be taken into account as a part of comprehensive assessment of quality of care.

\section{Theoretical Framework}

This research is an attempt to formulate a conceptual framework by means of a categorization scheme. It encompasses selected indicators that can measure outcome in the form of patient satisfaction. That is one of these indicators that is accepted globally as given by Donabedian who describes indicator as being structure, process or outcome in nature (Donabedian, 1980; Donabedian, 2003). Structure indicators are based on healthcare system that constitutes of doctors and paramedic staff, training, and equipment collectively. The health care system and the individuals in society and their interaction constitute structure. Mere existence of health care does not ensure appropriateness of process and their outcome. Process indicator of quality refers to the things done to and for the patient by practitioners in the course of treatment. Process relates to interaction between the patient and health care provider (Vahé , et al., 2002). Patient satisfaction is the actual measure of clinical services that are being offered. The main interaction between Health Care System and Patients outcome is measured by selecting and following "Key Process Indicators" (Kelly et al., 2006)

\section{Aim of the study}

This study amid to assess the client satisfaction of the reformed health services at rural health units/ centers.

\section{Subject and methods}

Research Design:-

Ex post facto research design was used in this study.

\section{Settings:-}

The study was conducted in two health units and two health centers from Ashmoon and Shebin Elkom Health Administration, Menofiya Governrate namely, Shanshour health units, Ashmoon health center, Kafr tanbedy family health unit and Shebin El-Kom family health center 


\section{Subject:-}

A convenience sample of 400 clients who agreed to participate in the study and visited the units or health centers during the time of data collection for follow up or recurrent visit, who were 12 years and older were recruited in the study. 100 clients were selected from each units and 100 clients were selected from each health centers.

\section{Tools of data collection:-}

The data collection tools, developed by the Technical Support Office (TSO, 2001) in The Ministry of Health and Population (MOHP), was adopted and utilized in this study, it included:

I- The Client Satisfaction Questionnaire: Used to measure client satisfaction about the health services at the Rural Health Units and Health Centers. It includes two parts:

Part 1; Demographic data of the client such as age, marital status, education level.

Part 2; It included 39 questions about management of Family record files - patient impression about the place the family medicine, clinic- dental clinic- health education ; social specialist, laboratory; pharmacy, the client suggestions to improve health services in the unit health - barriers to utilization of health services in the Units and Health Centers.

\section{Scoring system:-}

The questionnaire included 39 questions with a total of 105 points, if patient sheet with the number equals or more than $75 \%$ of the total points ( 77 degree or more) it means that the patient is satisfied and if the number is less than $75 \%$ (less than 77 degree) it means that the patient is not satisfied.

II-The observational checklist: It was used by the researcher to measures the quality of the health services in the pre mentioned units and health centers, using the Accreditation tool developed by TSO, (2001). It covered the following parts: 1-Patient right , 2-environmental safety 3-clinical safety, 4- infection control, 5- employee health program , 6- Pharmacy, 7-Laboratory, 8- emergency care, 9- housekeeping, 10-laundry, 11-management of information ,12- quality Improvement program, 13- family practice model, and 14- management of the unit /health centers. The total questions numbers were 227.

\section{Scoring system:}

For application of quality measurement tool in the units, calculating the total score for each group of questions under each subtitle and divided it by 100 if the result is $75 \%$ or more it means that the items are accepted, and consider not accepted if less than $75 \%$.

\section{Methods}

I- An approval letter was directed from the Dean of Faculty of Nursing, Menoufiya University, to obtain the agreement of the Health Administration Manager to conduct the research. The Health

Administration Manager gave an agreement to the researcher directed to every Manger in the Health Units and Health centers. II- Before starting the data collection, the aim of the study was explained to each manger and nursing supervisor in the Health Units and Health Centers. Data were collected during the period from first of November 2011to first of April 2012.

III-Filling the Client Satisfaction Questionnaire took about 15 minutes before client inters the clinic or while waiting for any procedure, to ask him/her about their satisfaction, suggestions and barriers and interviews and to collect data from the patient.

IV- Observation of the units / centers was done by observing all accreditation standers based on the Accreditation tool developed by TSO, (2001). The researcher audited all behaviors in each setting. The observation took about one month, (one week for each unit and for the each health center).

\section{Ethical Considerations:-}

The agreements for participation of the subjects were taken after the purpose of the study was explained to them. Before data collection, the clients were informed about the aim of the study. They were given an opportunity to refuse to participate and they were notified that they could withdraw at any stage of the research. Also they were assured that, the information would remain confidential and used for the research purpose only.

Pilot Study:-

A pilot study was conducted using the constructed questionnaire. The pilot study used 40 clients to evaluate the questionnaire for clarity, time to fill the questionnaire and its applicability. Then they were excluded from the total sample. 


\section{Statistical analysis:}

The data collected were tabulated and analyzed using SPSS (statistical package for the social science software) statistical package version 11 on IBM compatible computer. Quantitative data were expressed as mean and standard deviation. Qualitative data were expressed as number and percentage.

\section{Results}

Table (1): Presented the number and percentage distribution of personal data of the clients. It shows that, the majority of the studied clients were females in the units and health centers, with a mean age between $33.52 \pm 10.92$ in Shebin Elkom health center. The majority of the studied clients were not working except for Kafer tanbedy health unit where $56 \%$ were working. In addition the majority of the clients were married.

Tables (2) Illustrated the distribution of the client satisfaction in the health units and health centers. The majority of the clients were satisfied from all health services in the units and health centers in Menofiya Governorate ,however, 25\% and 21\%of the clients in Kafr tanbedy and Shanshour health units were not satisfied Table (3) Presented the distribution of the reported client suggestions to improve health services in the health units / health centers. A percentage of the studied sample suggested the availability of the specialists and female gynecologist in Kafer Tanbedy (62\%) Shanshour (49\%), Shebin Elkom health centers (56\%).Also, availability of medication and providing Sonar and operation room were suggested by $(10 \%, 10 \%, 21 \%)$, in Kafer Tanbedy, Shebin Elkom, and Shanshour health unit respectively. None of the clients in Ashmoon health center reported any suggestion.

Table (4) Distribution of the reported barriers of clients to utilization of the health services. The clients in Ashmoon health center do not report any barriers they were all satisfied from the services. While clients from Kafr tanbedy and Shebin Elkom health center, reported barriers to utilize the health services. Regarding barriers from privacy during consultation, all the studied clients in Ashmoon health center were satisfied compared to $54 \%$ in Kafr tanbedy health unit , in addition, 34\% from the studied sample reported no physical examination in Kafer Tanbedy health unit more in Shanshour health unit . Regarding buying drugs from outside, $44 \%$ of the clients in Kafer Tanbedy, 19\% in Shebin Elkom, 12\% in Shanshour health unit reported that they usually buy drugs from outside the unit.

Table (5): Showed the distribution of the quality indicators in the health units and centers. This table clarifies that all the quality indicators observed are accepted in Ashmoon health center followed by Shebin Elkom health center where only workers health quality indicator were not accepted. However, in Shanshour (HU) the majority of the observed quality indicators items are not accepted except for sterilization and management of the facility. Also the majority of the observed quality indicator items were not accepted in Kafer Tanbedy health unit.

\section{Discussion}

Quality of health care is the degree of the most optimal degree of health outcomes by delivery of effective, efficient and cost-benefit professional health services to people and communities (Tafreshi et al., 2007). Moreover, emphasis on technical quality and interaction with the patient are important. The technical quality of care includes appropriateness of services provided and the skills with which appropriate care is performed. The ability of health care providers to meet expectations of patients is an important quality parameter (Winkel \&Zhang, 2007).

This study amid to assess the client satisfaction of the reformed health services at rural health units/ centers. The findings indicated that all of the clients in Ashmoon health center, reported that they are satisfied with the ease of getting the family file and satisfied with the communication with the employee in the family room than in Shebin Elkom health center and Shanshour health unit. Also, more than one third of the clients in Kafr Tanbedy health unit reported that they are not satisfied with the communication with the employee in the family room. This finding in Kafer Tanbedy health unit come on the same line with the result of the study conducted in Tanzania by Muhondwa et al (2008) who reported that, the patients expressed dissatisfaction with the attitudes and behaviors of health personnel. In congruence with the present study, Ahmed (2007) concluded that good communication with patients is the first step to fell patient with confidence. Distribution of the client satisfaction in whole sheet showed that the majority of the clients were satisfied from all health services in the units and health centers however, less than one third of the clients in Kafer Tanbedy and Shanshour health unit were not satisfied. This study come on the same line with the result of the study conducted in Alexandria by Gadallah etal, (2011) who reported that, patient satisfaction was higher in reformed public health units / centers. regarding to the distribution of the client suggestions to improve health services in the units / health centers. None of the clients in Ashmoon health center reported any suggestion. The majority of the studied sample suggested a need for specialists and female gynecologist (in Kafer Tanbedy health unit 62\%, Shanshour health unit 49\%, and Shebin Elkomhealth center 56\%. Also, availability of medication and providing Sonar and operation room were suggested by clients at Kafer Tanbedy, Shebin Elkom and Shanshour health unit 
respectively due to their dissatisfaction. This study come on the same line with the result of the study by $\mathbf{E l}$ Zanaty, (2008) who reported that, the suggestions to improve the health care in the units; included, increase the number of physicians, have female gynecologist, ensure the continuous supply of drugs and continuous supply of resources to maintaining quality services.

As for quality indicators, the findings showed that, Ashmoon health center and Shebin Elkom health center had accepted total score, compared to Kafer Tanbedy and Shanshour health unit. As for Shanshour health unit it was the lowest in the four units in patient rights, environmental safety, infection control and workers health, followed by Kafer Tanbedy health unit. This difference between these units may be due to better recourses as observed by the researcher and better environmental safety. Also it could be due to the frequent visits and auditing from the Health Administration and better recourses allocated to the health center and units. This study come on the same line with the result of the study conduct by Momen, (2007) who reported that, the quality indicators in reformed unit/ centers are higher and applicable as the environmental safety, patient right, infection control. Finally (Muhondwa,2008) stated that customers can assess the delivery of health care services and make valid conclusions about the quality of care rendered to themselves. They must recognize that quality assurance and quality management programme need to impact on patient satisfaction in addition to improve professionally determined technical aspects of quality of health care.

\section{Conclusion}

In the light of the present study findings, it can be concluded that: the majority of the clients in Ashmoon health center and Kafer Tanbedy health unit were satisfied from all health services in the unit and health center. Clients in Shanshour health unit where less satisfied. The majority of clients in all units reported that, the unit was clean when attending except for Shanshour health unit. As for the quality indicators observed they were all accepted at Ashmoon, Shebin Elkom health centers compared to Kafer Tanbedy and Shanshour health unit .

\section{Recommendations}

- According the client's culture background there is a need to have female gynecologist in the health unit /centers

- Effective communication skills with clients to ensure proper quality of the services.

- It 's suggested to recruit social specialist in the units and health care centers.

- Continuous supply of resources as drugs, cleansing equipment to promote cleansing in the units/ health centers and to maintain quality services.

- Availability of the drugs.

- Activate the health education seminars in the unit and health centers to increase patients awareness about quality of services.

- For further research it is recommended that all stakeholders like doctors, practitioners, paramedics, administration, should be given chance to express their point of view.

- Continuous visitation and auditing of the health unit/ center.

\section{References}

[1]. Abdel-Razik M., Tawfik A., Hemeda S., El-Rabbat M., Abou-Zeina H. and Abdel-Latif G. Quality of Primary Health Care Services within the Framework of The National Accreditation Program. Australian Journal of Basic and Applied Sciences, 6(3), 2012, 12-18. Located at: www.insipub.com/ajbas/ March/12-18.pdf

[2]. Ahmed, H. A. Developing and validating standards for operating rooms at Benha University Hospital. Unpublished doctorate thesis in Nursing services Administration, Faculty of Nursing, Benha University, Egypt.2007.

[3]. Al-Tehewy M., Salem B., Habil I., And EL Okdai S. Evaluation of accreditation program in non-governmental organizations' health units in Egypt: short-term outcomes. International Journal for Quality in Health Care 21, (3), 2009 183-189. Located at: http://intqhc. oxfordjournals.org/content/21/3/183.full

[4]. Al-Doghaither AH, Abdelrhman BM, Saeed AA. Patients' satisfaction with physician's services in primary health care centers in Kuwait city, Kuwait.( JR Soc Health; 120:170-174. 2000).

[5]. Boshoff, C. \& Gray, B. The Relationship between Service Quality, Customer Satisfaction and Buying Intentions in the Private Hospital Industry". South African, Journal of Business Management, Vol.35 (4), 2004, pp. 27-37.

[6]. Bu-Alayyan ,S., Mostafa,A., Al-Etaibi,B., Sorkhou,E.\& Al-Taher,H. Patient Satisfaction with Primary Health Care Services in Kuwait. Kuwait Medical Journal 2008, 40 (1), 2008 , 25-30.

[7]. Doherty A. Measurement of Patient Satisfaction Health Strategy Implementation Project: 10-11, 2003.

[8]. Donabedian A. An Introduction to Quality Assurance in Health Care, (Oxford University Press 2003).

[9]. Donabedian A. "Explorations in Quality Assessment and Monitoring", The Definition of Quality and Approaches to its Assessment, Ann Arbor: Health Administration Press, Vol. 1, 1980.

[10]. El-Zanaty \&Associates. Egypt Service Provision Assessment Survey 2004. MOHP, USAID, ORC, Macro. located at: www.egypt.unfpa.org/.../1828cf97-c4b3-46bb-b5fa-d845a127ca8f.pdf, 2005.

[11]. Gadallah M., Allam M., Ahmed A., and El-Shabrawy E. .Are patients and healthcare providers satisfied with health sector reform implemented in family health centers? Downloaded from qualitysafety.bmj.comPublished by group.bmj.com.located at: http://qualitysafety. bmj.com/content/19/6/1.3.full.html, 2011. 
[12]. Kelley, Edward, Hurst, Jeremy, “OECD Health Working Papers no. 23 Health Care Quality Indicators Project Conceptual Framework Paper", Organisation de Coopération et de Développement Economiques Organisation for Economic Co-operation and Development, 2006.

[13]. Ministry of health and population., and Central Department for Technical Support and Projects. Family Health Fund and Contracting Strategy (Chapter 6): Family Health Facility Implementation Manual. Version 2. Located at: www.egypt.unfpa.org/.../1828cf97-c4b3-46bb-b5fa-d845a127ca8f.pdf, 2004 .

[14]. Momen O. Study the effect of the health sector reform program on the outcome of health services provided through the family medicine. 2007.

[15]. Muhondwa, E. et.al. Patient Satisfaction at The Muhimbili National Hospital in Dar Es Salaam, Tanzania, East African Journal of Public Health Volume 5 :( 2 ), 2008.

[16]. Muiruri,E.W. \& Ayodo,E. Factors Affecting Provision of Service Quality in the Public Health Sector International Journal of Humanities and Social Science Vol. 2 No. 13; July, 2012.

[17]. Pan American Health Organization. Maximizing Quality of Care through Health Sector Reform: The Role of Quality Assurance Strategies, Quality Assurance Project. LACHSR REPORT NO. 64: 7-9. Located at: http://www.hciproject.org/sites/default/files/MaximizingQualityinHealthSectorReform.LACHRS\%20Report\%2064.pdf , 2005.

[18]. Shaw C Evaluating accreditation. Int J Qual Health Care;15:455-6. Located at:www.health.org.uk/,2003.

[19]. Tafreshi, A. Nurses' perspectives on quality of nursing care: Aqualitative study in Iran, International Journal of Health Care quality assurance: 20(4) 320-328, 2007 .

[20]. Tam, J. L. M. Examining The Dynamics of Consumer Expectations in a Chinese Technologies ${ }^{\text {ee }}$. Journal of Marketing. Vol. 66, (3), pp. 98-111, 2005.

[21]. The International Bank for Reconstruction and Development / The World Bank. Health Systems. Washington DC 20433:1. Located at: www.worldbank.org, 2006.

[22]. Vahé, A,Kazandjian, Nikolas, Matthes, and Karol, G. Wicker, “Are performance indicators generic? The international experience of the Quality Indicator Project", Journal of Evaluation in Clinical Practice, 9 (2), 266-267, 2002.

[23]. Winkel, P. \& Zhang, N.F. Statistical development of quality in medicine, $1^{\text {st }}$ ed, John Wiley and sone company, Great Britain pp: 10. 2007.

Tables

Table (1): Distribution of Personal Data of Clients in the Study Settings ( no. $=400$ )

\begin{tabular}{|c|c|c|c|c|c|c|c|c|}
\hline Personal data & \multicolumn{2}{|c|}{$\begin{array}{l}\text { Kafr tanbedy (HU) } \\
(n=100)\end{array}$} & \multicolumn{2}{|c|}{$\begin{array}{l}\operatorname{Ashmoon}(\mathrm{HC}) \\
(\mathrm{n}=100)\end{array}$} & \multicolumn{2}{|c|}{$\begin{array}{l}\text { Shebin Elkom (HC) } \\
(\mathrm{n}=100)\end{array}$} & \multicolumn{2}{|c|}{$\begin{array}{l}\text { Shanshour(HU) } \\
(n=100)\end{array}$} \\
\hline $\begin{array}{l}\text { Gender: } \\
\text { Male } \\
\text { Female }\end{array}$ & $\begin{array}{l}22 \\
78\end{array}$ & $\begin{array}{l}22.0 \\
78.0\end{array}$ & $\begin{array}{l}22 \\
78\end{array}$ & $\begin{array}{l}22.0 \\
78.0\end{array}$ & $\begin{array}{l}30 \\
70\end{array}$ & $\begin{array}{l}30.0 \\
70.0\end{array}$ & $\begin{array}{l}27 \\
73\end{array}$ & $\begin{array}{l}27.0 \\
73.0\end{array}$ \\
\hline Age in years $X \pm S D$ & \multicolumn{2}{|c|}{$34.1 \pm 8.92$} & \multicolumn{2}{|c|}{$35.33 \pm 10.06$} & \multicolumn{2}{|c|}{$33 . .52 \pm 10.92$} & \multicolumn{2}{|c|}{$36.06 \pm 9.09$} \\
\hline $\begin{array}{l}\text { Job: } \\
\text { working } \\
\text { Not working }\end{array}$ & $\begin{array}{l}56 \\
44 \\
\end{array}$ & $\begin{array}{l}56.0 \\
44.0 \\
\end{array}$ & $\begin{array}{l}24 \\
76 \\
\end{array}$ & $\begin{array}{l}24,0 \\
76.0 \\
\end{array}$ & $\begin{array}{l}33 \\
67 \\
\end{array}$ & $\begin{array}{r}33.0 \\
67.0 \\
\end{array}$ & $\begin{array}{l}26 \\
74 \\
\end{array}$ & $\begin{array}{l}26.0 \\
74.0 \\
\end{array}$ \\
\hline $\begin{array}{l}\text { Educational level: } \\
\text { Basic } \\
\text { Secondary } \\
\text { Diploma } \\
\text { University }\end{array}$ & $\begin{array}{l}29 \\
29 \\
32 \\
10\end{array}$ & $\begin{array}{l}29.0 \\
29.0 \\
32.0 \\
10.0\end{array}$ & $\begin{array}{l}17 \\
31 \\
41 \\
11\end{array}$ & $\begin{array}{l}17.0 \\
31.0 \\
41.0 \\
11.0\end{array}$ & $\begin{array}{l}35 \\
11 \\
41 \\
23\end{array}$ & $\begin{array}{l}35.0 \\
11.0 \\
41.0 \\
23.0\end{array}$ & $\begin{array}{l}27 \\
32 \\
31 \\
10\end{array}$ & $\begin{array}{l}27.0 \\
32.0 \\
31.0 \\
10.0\end{array}$ \\
\hline
\end{tabular}

Table (2): Distribution of the Client Satisfaction in the Health Units and Health Centers. (no.=400)

\begin{tabular}{|l|c|c|c|c|}
\hline $\begin{array}{l}\text { Total client } \\
\text { Opinion }\end{array}$ & $\begin{array}{l}\text { Kafr tanbedy (HU) } \\
(\mathbf{n}=\mathbf{1 0 0})\end{array}$ & $\begin{array}{l}\text { Ashmoon(HC) } \\
(\mathbf{n}=\mathbf{1 0 0})\end{array}$ & $\begin{array}{l}\text { Shebin Elkom (HC) } \\
(\mathbf{n}=\mathbf{1 0 0})\end{array}$ & $\begin{array}{l}\text { Shanshour(HU) } \\
(\mathbf{n}=\mathbf{1 0 0})\end{array}$ \\
\hline Satisfied & 75 & 100.0 & 99 & 79.0 \\
\hline Not satisfied & 25 & 0.0 & 1 & 21.0 \\
\hline
\end{tabular}

Table (3): Distribution of the reported client suggestions to improve health services in the health units / health centers. $($ no. $=400)$

\begin{tabular}{|c|c|c|c|c|c|c|c|c|}
\hline \multirow[t]{2}{*}{ Suggestions } & \multicolumn{2}{|c|}{$\begin{array}{l}\text { Kafr tanbedy }(\mathrm{HU}) \\
(\mathrm{n}=100)\end{array}$} & \multicolumn{2}{|c|}{$\begin{array}{l}\operatorname{Ashmoon}(\mathrm{HC}) \\
(\mathrm{n}=100)\end{array}$} & \multicolumn{2}{|c|}{$\begin{array}{l}\text { Shebin Elkom }(\mathrm{HC}) \\
(\mathrm{n}=100)\end{array}$} & \multicolumn{2}{|c|}{$\begin{array}{l}\text { Shanshour(HU) } \\
(n=100)\end{array}$} \\
\hline & no. & $\%$ & no. & $\%$ & no. & $\%$ & no. & $\%$ \\
\hline $\begin{array}{l}\text { The medication should } \\
\text { be available all times }\end{array}$ & 28 & $28 \%$ & 0 & $0.0 \%$ & 34 & $34 \%$ & 30 & $30 \%$ \\
\hline $\begin{array}{l}\text { Availability of the } \\
\text { specialists \& female } \\
\text { gynecologist }\end{array}$ & 62 & $62 \%$ & 0 & $0.0 \%$ & 56 & $56 \%$ & 49 & $49 \%$ \\
\hline $\begin{array}{l}\text { Providing sonar and } \\
\text { operations room }\end{array}$ & 10 & $10 \%$ & 0 & $0.0 \%$ & 10 & $10 \%$ & 21 & $21 \%$ \\
\hline
\end{tabular}


Table (4): Distribution of the Reported Barriers to Health Services Utilization in the Health Units and Health Centers:

\begin{tabular}{|c|c|c|c|c|c|c|c|c|}
\hline \multirow[t]{2}{*}{ Reported barriers } & \multicolumn{2}{|c|}{$\begin{array}{l}\text { Kafr tanbedy }(\mathrm{HU}) \\
(\mathrm{n}=100)\end{array}$} & \multicolumn{2}{|c|}{$\begin{array}{l}\operatorname{Ashmoon}(\mathrm{HC}) \\
(\mathrm{n}=\mathbf{1 0 0})\end{array}$} & \multicolumn{2}{|c|}{$\begin{array}{l}\text { Shebin Elkom (HC) } \\
(\mathrm{n}=100)\end{array}$} & \multicolumn{2}{|c|}{$\begin{array}{l}\text { Shanshour(HU) } \\
(n=100)\end{array}$} \\
\hline & No. & $\%$ & No. & $\%$ & No. & $\%$ & No. & $\%$ \\
\hline $\begin{array}{l}\text { Privacy during } \\
\text { consultation } \\
\text { Yes } \\
\text { Sometimes } \\
\text { No }\end{array}$ & $\begin{array}{l}54 \\
32 \\
14 \\
\end{array}$ & $\begin{array}{l}54.0 \\
32.0 \\
14.0\end{array}$ & $\begin{array}{l}100 \\
0 \\
0\end{array}$ & $\begin{array}{l}100.0 \\
0.0 \\
0.0\end{array}$ & $\begin{array}{l}98 \\
2 \\
0 \\
\end{array}$ & $\begin{array}{l}98.0 \\
2.0 \\
0.0 \\
\end{array}$ & $\begin{array}{l}64 \\
27 \\
9 \\
\end{array}$ & $\begin{array}{l}64.0 \\
27.0 \\
9.0 \\
\end{array}$ \\
\hline $\begin{array}{l}\text { Do the doctor } \\
\text { examine } \\
\text { you physically? } \\
\text { Yes } \\
\text { Sometimes } \\
\text { No }\end{array}$ & $\begin{array}{l}44 \\
22 \\
34\end{array}$ & $\begin{array}{l}44.0 \\
22.0 \\
34.0\end{array}$ & $\begin{array}{l}100 \\
0 \\
0\end{array}$ & $\begin{array}{l}100.0 \\
0.0 \\
0.0\end{array}$ & $\begin{array}{l}95 \\
5 \\
0 \\
\end{array}$ & $\begin{array}{l}95.0 \\
5.0 \\
0.0 \\
\end{array}$ & $\begin{array}{l}79 \\
5 \\
16 \\
\end{array}$ & $\begin{array}{l}79.0 \\
5.0 \\
16.0 \\
\end{array}$ \\
\hline $\begin{array}{l}\text { Do you buy } \\
\text { drugs from outside } \\
\text { the unit? } \\
\text { Yes } \\
\text { Sometimes } \\
\text { No }\end{array}$ & $\begin{array}{l}44 \\
30 \\
26\end{array}$ & $\begin{array}{l}44.0 \\
30.0 \\
26.0\end{array}$ & $\begin{array}{l}0 \\
2 \\
98\end{array}$ & $\begin{array}{l}0.0 \\
2.0 \\
98.0\end{array}$ & $\begin{array}{l}19 \\
22 \\
59\end{array}$ & $\begin{array}{l}19.0 \\
22.0 \\
59.0\end{array}$ & $\begin{array}{l}12 \\
23 \\
65\end{array}$ & $\begin{array}{l}12.0 \\
23.0 \\
65.0\end{array}$ \\
\hline $\begin{array}{l}\text { Availability of } \\
\text { the Specialists } \\
\text { \& female } \\
\text { gynecologist } \\
\text { Yes } \\
\text { Sometimes } \\
\text { No }\end{array}$ & $\begin{array}{l}62 \\
18 \\
20\end{array}$ & $\begin{array}{l}62.0 \\
18.0 \\
20.0\end{array}$ & $\begin{array}{l}0 \\
0 \\
0\end{array}$ & $\begin{array}{l}0.0 \\
0.0 \\
0.0\end{array}$ & $\begin{array}{l}56 \\
17 \\
27\end{array}$ & $\begin{array}{l}56.0 \\
17.0 \\
27.0\end{array}$ & $\begin{array}{l}49 \\
23 \\
28\end{array}$ & $\begin{array}{l}49.0 \\
23.0 \\
28.0\end{array}$ \\
\hline
\end{tabular}

Table (5): Distribution of the Health Services in the Health Units and Health Centers Regarding the Quality Indicators:

\begin{tabular}{|c|c|c|c|c|c|c|c|c|}
\hline \multirow[t]{2}{*}{ Quality Indicators } & \multicolumn{2}{|c|}{$\begin{array}{l}\text { Kafr tanbedy }(\mathrm{HU}) \\
(\mathrm{n}=100)\end{array}$} & \multicolumn{2}{|c|}{$\begin{array}{l}\operatorname{Ashmoon}(\mathrm{HC}) \\
(\mathrm{n}=100)\end{array}$} & \multicolumn{2}{|c|}{$\begin{array}{l}\text { Shebin Elkom (HC) } \\
(\mathrm{n}=100)\end{array}$} & \multicolumn{2}{|c|}{$\begin{array}{l}\text { Shanshour(HU) } \\
(n=100)\end{array}$} \\
\hline & Accept & Not accept & Accept & $\begin{array}{l}\text { Not } \\
\text { accept }\end{array}$ & Accept & Not accept & Accept & $\begin{array}{l}\text { Not } \\
\text { accept }\end{array}$ \\
\hline Patient right & 0 & 1 & 1 & 0 & 1 & 0 & 0 & 1 \\
\hline Environmental safety & 1 & 0 & 1 & 0 & 1 & 0 & 0 & 1 \\
\hline Sterilization & 0 & 1 & 1 & 0 & 1 & 0 & 1 & 0 \\
\hline Infection control & 1 & 0 & 1 & 0 & 1 & 0 & 0 & 1 \\
\hline Workers health & 0 & 1 & 1 & 0 & 0 & 1 & 0 & 1 \\
\hline Pharmacy: & 0 & 1 & 1 & 0 & 1 & 0 & 0 & 1 \\
\hline Laboratory & 1 & 0 & 1 & 0 & 1 & 0 & 0 & 1 \\
\hline Emergency room & 1 & 0 & 1 & 0 & 1 & 0 & 0 & 1 \\
\hline Cleansing & 1 & 0 & 1 & 0 & 1 & 0 & 0 & 1 \\
\hline Landry & 1 & 0 & 1 & 0 & 1 & 0 & 0 & 1 \\
\hline Management of information & 0 & 1 & 1 & 0 & 1 & 0 & 0 & 1 \\
\hline $\begin{array}{l}\text { Quality improvement } \\
\text { Program }\end{array}$ & 0 & 1 & 1 & 0 & 1 & 0 & 0 & 1 \\
\hline Family practice model: & 0 & 1 & 1 & 0 & 1 & 0 & 0 & 1 \\
\hline Management of the Facility & 0 & 1 & 1 & 0 & 1 & 0 & 1 & 0 \\
\hline
\end{tabular}

